\title{
Overwintering Stages of Pseudosclerotia Development for Monilinia vaccinii-corymbosi, Causal Agent of Mummy Berry Disease on Highbush Blueberry in North America
}

\begin{abstract}
Jade Florence, Healthy Food and Farm Director, Northwest Center for Alternatives to Pesticides, Boise, ID 83706 (former Graduate Research Assistant and Extension Plant Pathology Specialist, Department of Botany and Plant Pathology, Oregon State University, Corvallis 97330); and Jay W. Pscheidt, Extension Plant Pathology Specialist, Department of Botany and Plant Pathology, Oregon State University, Corvallis 97330
\end{abstract}

Accepted for publication 19 July 2016. Published 15 August 2016.

Florence, J., and Pscheidt, J. W. 2016. Overwintering stages of pseudosclerotia development for Monilinia vaccinii-corymbosi, causal agent of mummy berry disease on highbush blueberry in North America. Plant Health Prog. 17:172-174.

Mummy berry, caused by Monilinia vaccinii-corymbosi (Reade) Honey, is an economically important disease of blueberries (Vaccinium spp.) throughout North America (Fig. 1) (Florence 2016). From late summer until early spring, pseudosclerotia rest on or close to the soil surface of blueberry fields. Pseudosclerotia develop apothecia and produce primary inoculum in coordination with floral bud break, the beginning of blueberry bush susceptibility. Secondary inoculum infects flowers and replaces developing fruit with a pseudosclerotium. Terminology for overwintering stages of $M$. vaccinii-corymbosi is inconsistent throughout the literature, and the progression from pseudosclerotium formation to carpogenic germination has never been cohesively and sequentially outlined. A comparison of the literature has exposed contradicting terms and overlapping definitions for pseudosclerotial stages, with some stages unnamed entirely. A developmental classification scheme was derived from existing terminology and observations of naturally conditioned pseudosclerotia over a two-year period in Corvallis, OR (Florence 2016). The proposed terminology for overwintering stages include maturation, dormancy, germination, emergence, differentiation, and carpogenic germination.

Maturation is the first stage of overwintering, being characterized in the literature by dehydration of infected berries, which become shriveled, pinkish-purple, and hardened, and abscise from the bush (Fig. 1) (Cox and Scherm 2001). Three maturity classes, based on exocarp color, have previously been described in the literature-brown, grey, and black (Cox and Scherm 2001). Brown and grey are the least mature classes, while black is the most mature (Cox and Scherm 2001). In a published study, survival, expressed as a percentage of intact pseudosclerotia 18 weeks after collection from blueberry fields in July, was highest for the black maturity class (Cox and Scherm 2001).

However, the black class should be categorized as a separate stage since the fruit skin is gone, revealing the dark melanized fungal tissue beneath (Fig. 2) (personal observation). Therefore, the dormancy stage is proposed based on field observations of a

Corresponding author: Jade Florence. Email: jade.a.florence@gmail.com.

doi:10.1094/PHP-BR-16-0003

C 2016 The American Phytopathological Society period of pseudosclerotial inactivity. In autumn, mature pseudosclerotia enter dormancy, when the exocarp (possibly the entire pericarp of the blueberry fruit) has shed to reveal black, melanized hyphae and chill hours (hours with a mean temperature $<7.2^{\circ} \mathrm{C}$ ) accumulate (Scherm et al. 2001).

Dormancy is followed by germination, defined in the literature as the stage occurring when pseudosclerotia form a stipe initial, which is a dark brown hardened protrusion, measuring $<5 \mathrm{~mm}$ (Fig. 3) (Milholland 1974). Typically, stipe initials are formed from the base of the pseudosclerotium, below the soil surface (Milholland 1974).

A germinated pseudosclerotium reaches the emergence stage when the stipe initial grows to between 5 to $15 \mathrm{~mm}$ (Fig. 4) (Milholland 1974). This stage is similar to germination, however the distinction has previously been made in the literature for experimental purposes (Milholland 1974). Stipe initials of pseudosclerotia in the emergence stage have sometimes been

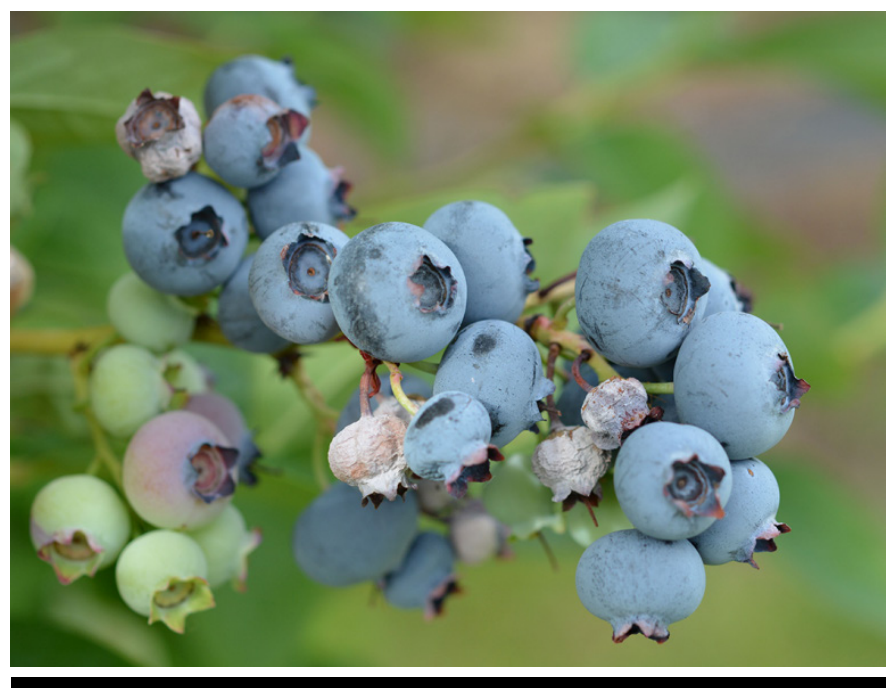

FIGURE 1

Maturation: pseudosclerotia (also called "mummies" due to their dry, shriveled appearance) of $M$. vaccinii-corymbosi mature on the blueberry bush alongside ripe berries. Maturation is characterized by dehydration of infected berries, which become shriveled, pinkish-purple, and hardened, and abscise from the bush. (Courtesy Dr. Jade Florence) 


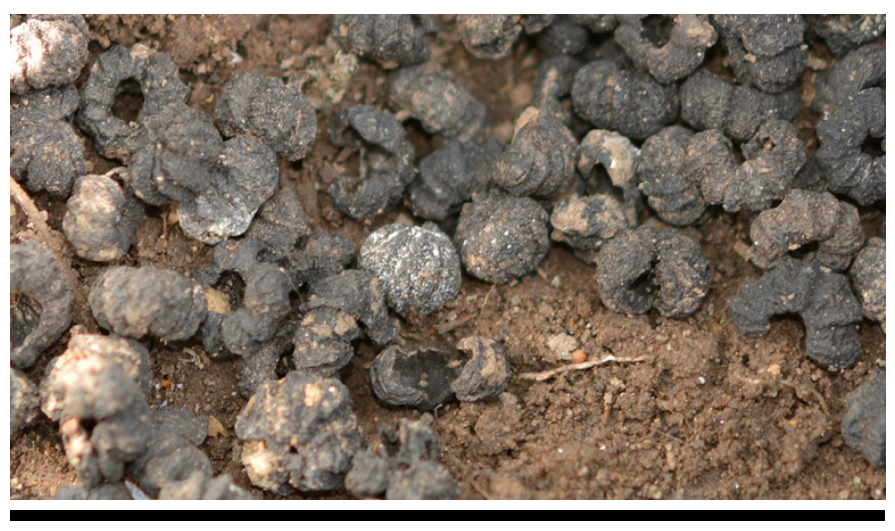

FIGURE 2

Dormancy: pseudosclerotia that have shed the host exocarp to reveal melanized hyphae overwinter on soil surface. (Courtesy Dr. Jade Florence)

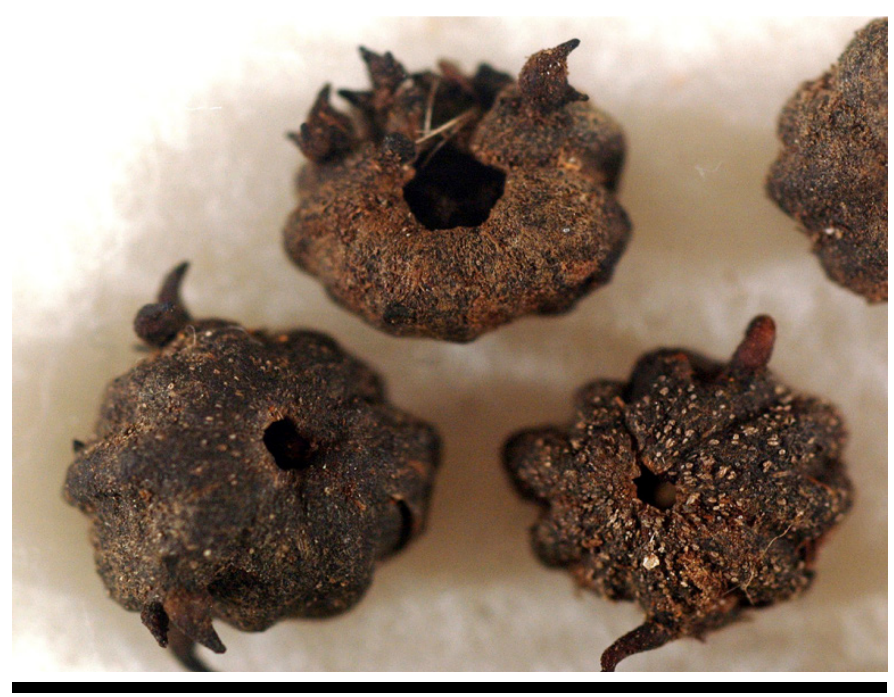

FIGURE 3

Germination: pseudosclerotia with stipe initials that are dark brown hardened protrusions, measuring $<5 \mathrm{~mm}$. (Courtesy Dr. Jay W. Pscheidt)

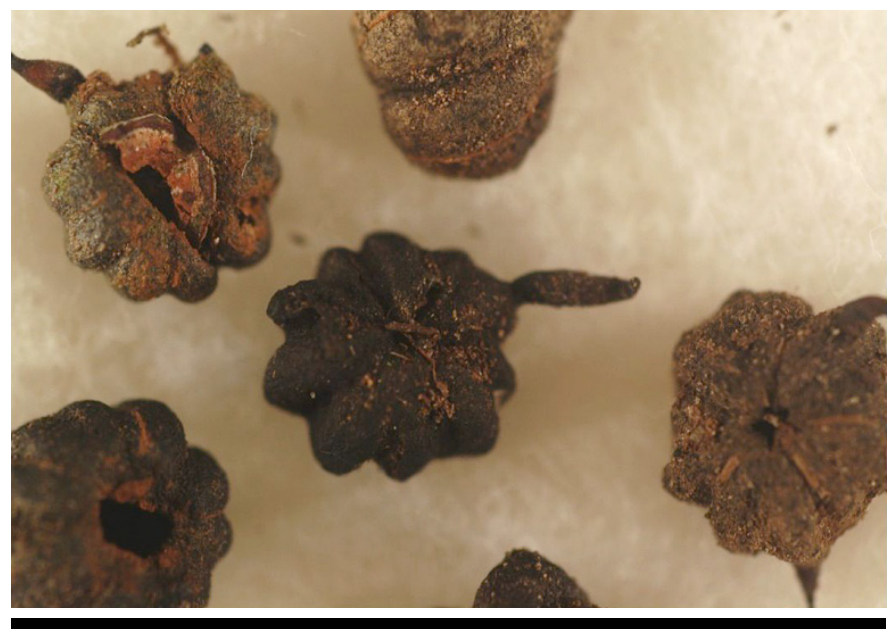

FIGURE 4

Emergence: stipe initials continue to elongate and grow to between 5 to $15 \mathrm{~mm}$. (Courtesy Dr. Jay W. Pscheidt) referred to as "fundaments" (Bristow 1979), but this term is not commonly used, nor is it found in mycological dictionaries, so the preferred term remains "stipe initial."

In the presence of adequate soil moisture, light, and degree days (base $7.2^{\circ} \mathrm{C}$ ) (Scherm et al. 2001), the stipe initials continue to develop in the differentiation stage, in which they elongate, become fleshy, turn a light brown color, and produce a tip indentation that may expand to a diameter up to $2 \mathrm{~mm}$ (Fig. 5). This stage is proposed to describe the visible changes that previously had been included in the emergence stage (Milholland 1974). During this stage, "a small depression appears at the tip of the stipe ..., but remains closed until the apothecium is formed and matures with the development of mature asci and ascospores" (Milholland 1974). Differentiation can last for several days (Florence 2016), and laboratory observations have shown that these stipes can elongate to a length of over $10 \mathrm{~cm}$ (Florence 2016).

An apothecium is formed when the tip indentation diameter reaches $2 \mathrm{~mm}$, and the pseudosclerotium enters the carpogenic germination stage, discharging ascospores (Fig. 6) (Wharton

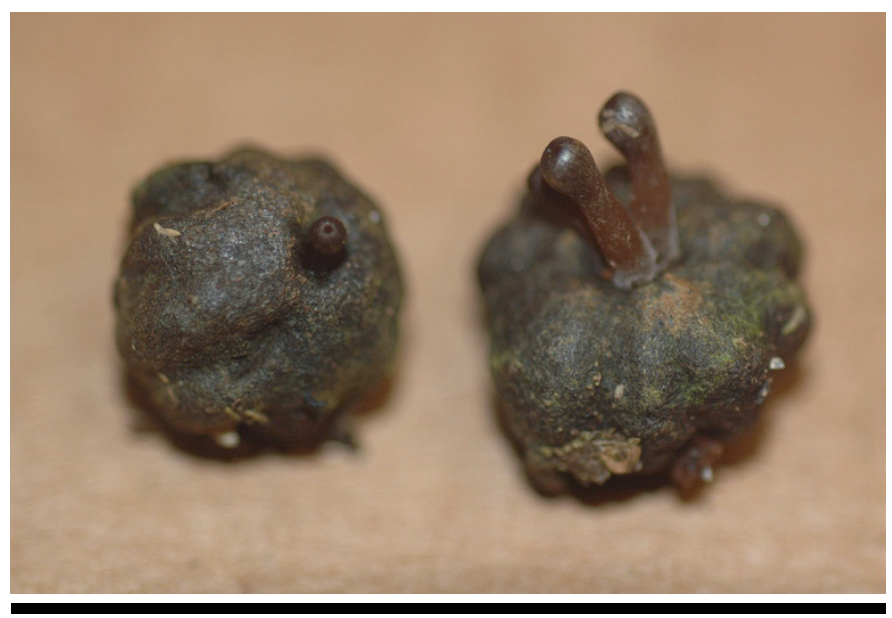

FIGURE 5

Differentiation: stipe initials elongate, become fleshy, turn a light brown color, and produce a tip indentation that may expand to a diameter up to $2 \mathrm{~mm}$. (Courtesy Dr. Jay W. Pscheidt)

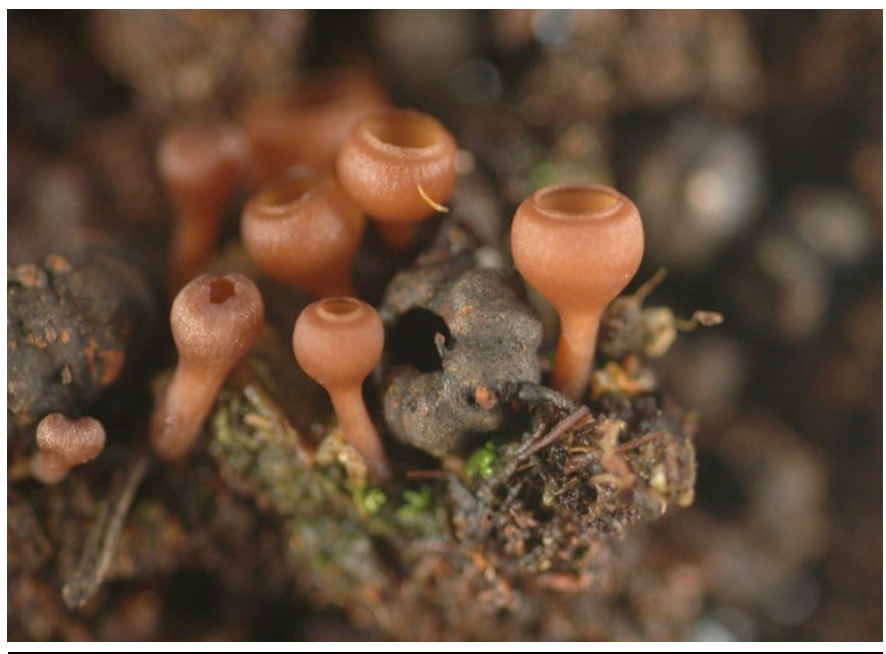

\section{FIGURE 6}

Carpogenic germination: the tips of the stipes have expanded wide enough ( $>2 \mathrm{~mm}$ ), to become cup-shaped apothecia. (Courtesy Dr. Jay W. Pscheidt) 
2005). Once an apothecium has begun to discharge spores, sporulation generally remains constant for 3 to 4 days before declining (Wharton 2005). These ascospores infect susceptible blueberry tissue and initiate the disease cycle.

These stages - maturation, dormancy, germination, emergence, differentiation, and carpogenic germination-form the foundation of $M$. vaccinii-corymbosi overwintering terminology. The standardization of these terms will allow for better communication regarding this pathogen.

\section{LITERATURE CITED}

Bristow, P. R. 1979. Mummy berry disease: Mummy germination. Pages 163 169 in: Proc. of the Fourth North American Blueberry Research Workers Conference. J. N. Moore, ed. Univ. of Arkansas, Fayetteville.

Cox, K. D., and Scherm, H. 2001. Oversummer survival of Monilinia vacciniicorymbosi in relation to pseudosclerotial maturity and soil surface environment. Plant Dis. 85:723-730.

Florence, J. 2016. Mulching to manage mummy berry of blueberry. Ph.D thesis. Oregon State University, Corvallis, Oregon.

Milholland, R. D. 1974. Factors affecting apothecium development of Monilinia vaccinii-corymbosi from mummified highbush blueberry fruit. Phytopathology 64:296-300.

Scherm, H., Savelle, A. T., and Pusey, P. L. 2001. Interactions between chillhours and degree-days affect carpogenic germination in Monilinia vaccinii-corymbosi. Phytopathology 91:77-83.

Wharton, P. S., and Schilder, A. M. C. 2005. Effect of temperature on apothecial longevity and ascospore discharge by apothecia of Monilinia vaccinii-corymbosi. Plant Dis. 89:397-403. 